\title{
ОСОБЛИВОСТІ ФОРМУВАННЯ НАВИЧОК ВЛУЧНОЇ СТРІЛЬБИ У ЗДОБУВАЧІВ ВИЩОЇ ОСВІТИ НАВЧАЛЬНИХ ЗАКЛАДІВ ІЗ СПЕЦИФІЧНИМИ УМОВАМИ НАВЧАННЯ
}

Геращенко О. С., Головацький О. О.

\begin{abstract}
У даній науковій статті розглянуто питання про практичне формування навичок влучної стрільби в процесі навчання курсантів вищих навчальних закладів зі специфічними умовами навчання. Обгрунтовано, що зазначена навичка об'єктивно вважається однією із найважливіших при здійсненні майбутніми поліцейськими своєї професійної діяльності. Визначено, що при вивченні курсантами вищих навчальних закладів зі специфічними умовами навчання вогневої підготовки необхідно не тільки навчити їх прийомам і правилам стрільби, але і психологічно підготувати їх до застосування зброї в умовах несення служби. Метою роботи є формування знань про навички влучної стрільби у курсантів вищих навчальних закладів зі специфічними умовами навчання під час навчання їх вогневої підготовки.

Ключові слова: вогнепальна зброя, курсант, стрілянина, навчальні заклади зі специфічними умовами навчання, влучність, психологічна напруга, навичка, формування навичок, вогнева підготовка.
\end{abstract}

В данной научной статье рассмотрен вопрос о практическом формировании навыков меткой стрельбы в процессе обучения курсантов высших учебных заведений со специфическими условиями обучения. Обосновано, что указанный навык объективно считается одним из важнейших при осуществлении будущими полицейскими своей профессиональной деятельности. Определено, что при изучении курсантами высших учебных заведений со специфическими условиями обучения огневой подготовки необходимо не только обучить их приемам и правилам стрельбы, но и психологически подготовить их к применению оружия в условиях несения службы. Целью работы является формирование знаний о навыках меткой стрельбы у курсантов высших учебных заведений со специфическими условиями обучения во время обучения их огневой подготовке.

Ключевые слова: огнестрельное оружие, курсант, стрельба, учебные заведения со специфическими условиями обучения, меткость, психологическое напряжение, навык, формирование навыков, огневая подготовка.

This scientific article reveals the issue of marksmanship skills formation in the course of teaching cadets in higher educational establishments with specific learning environment. It was justified that abovementioned skill is objectively considered to be one of the most significant in future policemen' professional activity. It was defined that the process of firearm training of cadets in higher educational establishments with specific learning environment requires teaching not only shooting techniques and rules, but also mental set to use weapons during a service. The aim of work is cadets' knowledge formation about marksmanship skills in the course of firearm training in higher educational establishments with specific learning environment.

It is revealed that one of the most frequent mistakes that occur during the production of a shot is a sharp pull on the trigger. It is noted that this error manifests itself in beginning shoot-

Геращенко О. С., Головацький О. О., 2019 ers who are just undergoing the process of learning the basics of controlling the trigger pull or those who have developed the wrong reflex of the indicated depression.

On the basis of the conducted training in firing training among cadets of higher educational institutions with specific learning conditions, the interrelation of reasons complicating the consistency of aiming and pulling the trigger actions with the changes occurring in the course of reflex reactions in the cadet's body was determined.

Identified as necessary and useful recommendations during the training sessions on fire training for cadets of educational institutions with specific learning conditions are the following: firing a shot against the background of natural "stability" without reacting to each minor deviation of the weapon from the aiming point; the implementation of techniques that are aimed at the observance of the arrows of motion smoothness.

Key words: firearm, cadet, shooting, educational, aiming accuracy, psychological tension, skill, skill formation, firearm training.

Постановка проблеми та її актуальність. Сьогодні особливу увагу привертає питання практичного формування навичок влучної стрільби в процесі навчання курсантів у вищих навчальних закладах із специфічними умовами навчання. Дане питання має значення для практичної діяльності поліцейських при виконанні ними службових обов'язків, адже вони уповноважені, а іноді і зобов'язані застосовувати вогнепальну зброю для припинення небезпечних протиправних дій злочинців (зокрема, в екстремальних ситуаціях).

Водночас питання індивідуальних тактичних способів дій із вогнепальною зброєю в процесі виконання поліцейськими повсякденних оперативно-службових завдань (затримання озброєного злочинця в квартирі, приватному секторі, громадському місці, будівлях і спорудах тощо) також заслуговує на окрему увагу. Поряд із розробкою навчальних програм з вогневої підготовки залишається у недостатній мірі вивченим процес формування у курсантів навичок влучної стрільби з вогнепальної зброї. Зауважимо, що ці аспекти займають чільне місце у практичній діяльності поліцейських.

Аналіз останніх досліджень і публікацій. Окремі аспекти підвищення рівня вогневої підготовки поліцейських, а також формування навичок влучної стрільби досліджувалися у працях М.І. Ануфрієва, С.М. Банаха, В.Р.Булачека, Г.Н.Будаг'янца, І.С. Винярчука, Ю.А. Лапутіної, О.М. Калиніченко, О.О. Юр'єва та інших авторів.

Метою даної наукової роботи $\epsilon$ визначення особливостей формування навичок влучної стрільби у здобувачів вищої освіти навчальних закладів із специфічними умовами навчання, а також розробка конкретних пропозицій і рекомендацій щодо підвищення рівня вогневої підготовки майбутніх поліцейських в Україні. 
Виклад основного матеріалу. Згідно із загальним правилом розробка та впровадження для курсантів вищих навчальних закладів із специфічними умовами навчання індивідуальної тактичної підготовки в стрільбі з пістолета неможлива без подальшого розвитку спеціальної навчальної дисципліни «Вогнева підготовка», яка передбачена навчальними планами. Нагадаємо, що вогнева підготовка передбачає комплекс заходів, спрямованих на вивчення поліцейським основ стрільби 3 вогнепальної зброї, правомірного іiі застосування (використання) та вдосконалення навичок безпечного поводження з нею, швидкісної та влучної стрільби по нерухомих і рухомих цілях, з різних положень, в обмежений час, в русі тощо [1].

У попередніх дослідженнях нами неодноразово було підкреслено, що розвиток індивідуальної тактичної підготовки та навичок влучної стрільби з вогнепальної зброї у курсантів має супроводжуватися об'єктивно закономірними інтеграційними процесами як на основі традиційних і класичних форм і методів викладання, так і на основі інноваційних методів (ситуативні вправи, тренінги, поліцейські квести). 3 огляду на це сьогодні стає актуальним об'єднання наявних знань, умінь і навичок вогневої і тактичної підготовки, узагальнення їх до рівня моделей і концепцій з подальшою розробкою теорії прикладної тактико-технічної підготовки в стрільбі з пістолета.

У контексті розглянутої проблеми слід відзначити, що основним завданням стрільця $є$ влучність кожного пострілу. Відомо, що влучний постріл досягається за рахунок купчастості стрільби та суміщення їі в центрі мішені. Влучна стрільба залежить від уміння стрільця виконувати в єдиному процесі три основні дії, такі як приціл (наведення і утримання зброї в районі (точці) прицілювання), утримання дихання і спуск курка (дві останні дії - це дії, пов'язані із натиском на спусковий гачок [2, с. 33].

Професійне натискання на спусковий гачок відіграє велику роль для здійснення влучного пострілу, а також $\epsilon$ головним показником підготовки стрільця. Як показує практика, більшість помилок під час виконання вправ з вогнепальною зброєю виникає виключно через неправильне натискання на спусковий гачок. Відзначимо, що навіть помилки під час прицілювання можуть показати влучний результат, але ось помилки, допущені під час натискання спускового гачка, неминуче призводять до незадовільних результатів.

Одна $з$ найбільш частих помилок, які трапляються під час здійснення пострілу, - це різке натискання на спусковий гачок. Особливістю даної дії $\epsilon$ те, що різке натискання на спусковий гачок супроводжується напругою груп м'язів, в результаті чого відбувається різке натискання правою рукою на рукоятку пістолета з натисканням на спусковий гачок не прямо назад, а вбік. Такі дії призводять до зміщення зброї, наслідком чого $\epsilon$ відсутність влучного пострілу. Інструктори-практики відзначають, що дана помилка проявляється у стрільців-початківців, які тільки вчаться основам контролю натискання на спусковий гачок, або ж у тих, які виробили неправильний рефлекс зазначеного натискання.

3 цього приводу цікавою $є$ думка деяких науковців. Так, О.О. Юр'єв серед інших причин, що ускладнюють узгодженість дій прицілювання і натиснення на спусковий гачок, відзначає те, що сам постріл супроводжу- ється сильним звуковим ефектом та віддачею зброї [3, с. 98]. Він наводить стандартну ситуацію. Якщо новачку дати навчальні (холості) патрони, він спокійно буде ними заряджати зброю, цілитися і натискати на спусковий гачок. Але як тільки він виконає один - два постріли бойовим патроном і відчує удар у плече від віддачі зброї, він буде поводитися інакше. Знаючи, що постріл супроводжуватиметься ударом в плече, стрілець разом з натисненням на спусковий гачок мимоволі напружуватиме м'язи і подаватиме плече вперед, щоб протидіяти удару. Отже, у цього стрільця на базі безумовного рефлексу сформується умовний рефлекс на очікуваний удар [3, с. 99].

Водночас вважаємо за необхідне до вказаного додати наступне. Як показує практика проведення занять з вогневої підготовки серед курсантів вищих навчальних закладів із специфічними умовами навчання, причини, що ускладнюють узгодженість дій прицілювання і натиснення на спусковий гачок, пов'язані зі змінами, що відбуваються у протіканні рефлекторних реакцій в організмі курсанта. По-перше, курсантові доводиться змінювати протікання деяких безумовних рефлексів. По-друге, у процесі освоєння нових рухів, фізіологічною основою чого $€$ утворення нових умовно-рефлекторних зв'язків, курсант постійно повинен контролювати себе, щоб не допустити утворення і закріплення у числі нових умовних зв' язків небажаних навичок, які можуть надалі мати шкідливий вплив на якість стрільби з вогнепальної зброї.

Слід зазначити, що якщо вчасно не виявити у курсантів, які проходять навчання вогневої підготовки, вищезазначені помилки, то вони переростають у вироблений рефлекс під час стрільби, що у свою чергу призводить до відсутності влучності. Потім доведеться докласти багато зусиль і часу, щоб позбутися напрацьованих зазначених негативних навичок.

У контексті викладеного зазначимо, що серед практикуючих тренерів поширена думка, що іноді легше навчити нового учня, ніж виправити у іншого стрільця вже засвоєну рухову навичку з помилками. Сьогодні ні у кого не викликає сумнівів умовно-рефлекторна та функціонально-структурна природа рухової навички. Порушення рухової навички стрільців можна інтерпретувати як утворення небажаних рухових умовних рефлексів. 3 огляду на це автоматизацію рухової дії не варто вважати показником ефективності, адже автоматичними можуть бути і помилкові варіанти рухових дій $[4$, c. 39].

На наш погляд, техніка влучної стрільби включає в себе розумовий контроль за натисканням на спусковий гачок, яке за своєю природою та технічним виконанням має бути плавним. Як було нами зазначено вище, головною проблемою у більшості курсантів під час навчання стрільбі з вогнепальної зброї $є$ різке натискання на спусковий гачок, що призводить до відсутності влучного пострілу та незадовільного виконання навчальної вправи. Вважаємо, що цьому сприяє сильне психологічне напруження курсанта. На підтвердження наведеного прикладу 0.О. Юр'єва зазначимо, що, виконуючи тренувальні вправи із незарядженою навчальною зброєю, всі курсанти можуть плавно натиснути на спусковий гачок, щоб при цьому зброя залишилася в нерухомому положенні. Однак, як тільки вони починають виконувати ці вправи з бойовою зброєю, напрацьований навик 
втрачається. Даний факт свідчить про те, що не всі курсанти здатні самостійно здолати страх перед пострілом.

Поряд із натисканням на спусковий гачок під час навчання стрільбі з вогнепальної зброї курсанти повинні здійснювати також такі рухи, як наведення зброї на ціль. У контексті настанов викладачів-тренерів або інструкторів про те, що виконувати постріл потрібно на фоні природної «стійкості», мається на увазі те, що не рекомендується терміново реагувати на кожне незначне відхилення зброї від точки прицілювання. Вважаємо ці настанови також необхідними та корисними під час проведення занять з вогневої підготовки у курсантів навчальних закладів зі специфічними умовами навчання.

До вказаного також слід додати, що корисними під час проведення занять з вогневої підготовки серед курсантів $\epsilon$ також методи, за якими вплив на дії стрільця здійснюється шляхом створення відповідних образів або установок. Прикладами подібних методів можуть бути, зокрема, створення відповідних образів, асоціацій. Наприклад, виконання пострілу має асоціюватися з наповненням та раптовим падінням краплини води. Також можна використовувати самонакази типу: «не чекайте моменту пострілу», «виконуйте постріл як неважливу дію». Корисними під час навчання курсантів можуть стати і прийоми, згідно з якими стрільцям пропонується дотримуватися плавності рухів.
Висновки. 3 огляду на наведене можна підсумувати, що практична значущість дослідження полягає у тому, що проведений аналіз методичних прийомів та настанов дозволяє розширити знання про особливості формування навичок влучної стрільби у здобувачів вищої освіти навчальних закладів із специфічними умовами навчання і може лягти в основу подальших розробок методичних підходів щодо навчання і вдосконалення техніки серед курсантів.

\section{Література}

1. Про затвердження Положення про організацію службової підготовки працівників Національної поліції України : Наказ Міністерства внутрішніх справ України від 26 січня 2016 року № 50. URL: http://zakon3.rada.gov.ua/laws/ show/z0260-16\#n1.

Геращенко О. С., кандидат юридичних наук, доцент, доцент кафедри тактико-спеціальної, вогневої та фізичної підготовки

Одеського державного університету внутрішніх справ

Головацький О. О., викладач кафедри тактико-спеціальної, вогневої та фізичної підготовки Одеського державного університету внутрішніх справ 